\title{
Kieran.Murphy@,Colorado.edu
}

\section{Haiti and the Black Box of Romanticism}

The camera obscura could be considered a "black box" of Romanticism. Unpacking it can give access to thoughts and transatlantic interactions that have been lost since their initial appearance hundreds of years ago. One of the main recovery efforts that helped locate this remarkable black box began with Sarah Kofman's study on the recurrent invocations during the nineteenth-century of the camera obscura as a theoretical model. ${ }^{1}$ Kofman brought to the fore the critical importance of this black box by showing how its image-making function deeply impacted the exploration of cognitive and epistemological questions in authors such as Rousseau, Marx, Nietzsche, and Freud. She observed that, over time, the meaning conveyed by the camera obscura shifted from transparency to opacity. Varying interpretations of the camera obscura had at least one thing in common, though. They manifested, often unwittingly, a fetishist disposition in European scientific thinking.

Auguste Comte was the first philosopher to consider this disposition through a theory that underlined the intimate link between modern science and fetishism. For the founder of positivism, fetishism is the true intellectual point of departure of humanity and therefore already contains in an immature form the power of speculation and practical reasoning characteristic of the scientific

\footnotetext{
${ }^{1}$ Sarah Kofman, Camera obscura, De l'idéologie (Paris: Éditions Galilée, 1973). The camera obscura "cannot be reduced either to a technological or a discursive object: it was a social amalgam in which its existence as a textual figure was never separable from its machinic uses." Jonathan Crary, Techniques of the Observer: On Vision and Modernity in the Nineteenth Century (Cambridge: MIT Press, 1990), 30-31. See also, Lee W Bailey, "Skull's Darkroom: The Camera Obscura and Subjectivity," in Philosophy of Technology: Practical, Historical and Other Dimensions, ed. Paul T. Durbin (Springer Netherlands, 1989). Philippe Ortel, La Littérature à l'ère de la photographie : enquête sur une révolution invisible (Nîmes: J. Chambon, 2002).
} 
mind. ${ }^{2}$ In the primordial stage of fetishism the outside world is considered a direct extension of one's life, will, and passions. The fetishist is then more invested in earthly matters and inclined to explore them than the polytheist, monotheist, and metaphysician, whose beliefs in supernatural, indirect, or transcendental causes divert them from empirically investigating their immediate surroundings. Georges Canguilhem has noted that Comte's rehabilitation of fetishism marked a break with the traditional Enlightenment idea of progress as the gradual attainment of perfection, which implied an intrinsic transformation of human nature, and the devalorization of the past. ${ }^{3}$ In Comte's positivist and evolutionist scheme, human intellectual development cannot transcend or devalorize fetishism because this primordial stage already manifests the fundamental dispositions that characterize the scientific mind in an immature form.

Comte's controversial revalorization of fetishism became particularly apparent in his 1850 s works, where, in provocative passages, he considers the logic of African fetishists far more rational and wise than the metaphysical "verbiage of the superb Germanic doctors." The transgressive racial implications of Comte's conception of fetishism would fully concretize in Anténor Firmin's Of the Equality of the Human Races: Positivist Anthropology (1885), where it became a cornerstone in the Haitian anthropologist's groundbreaking critique of nineteenth-century scientific racism. Firmin's innovations also derived from his pioneering experience as a citizen of the first postcolonial black state. The achievements of the self-emancipated African slaves and their descendants in Haiti become in his study undeniable evidence of black intellectual ability. ${ }^{5}$

\footnotetext{
${ }^{2}$ Auguste Comte, Cours de philosophie positive, vol. 5 (Paris: J.P. Baillère et Fils, 1864), 5, 25-30.

${ }^{3}$ Georges Canguilhem, Études d'histoire et de philosophie des sciences, 3 ed. (Paris: Librairie philosophique J. Vrin, 1975), 97. See also Auguste Comte, Système de politique positive, vol. 3 (Paris: Librairie des Corps Impériaux des Ponts et Chaussées et des Mines, 1853), 88.

${ }^{4}$ Comte, Système de politique positive, 99, 121, 56.

${ }^{5}$ Joseph-Anténor Firmin, De l'égalité des races humaines (anthropologie positive) (Paris: F. Pichon, 1885), 504-5, 24.
} 
Together with positivism, Haiti's unprecedented postcolonial experiment helped Firmin undermine the epistemological framework that was leading European scientists astray. The Haitian critical tradition of interrogating European science began when self-emancipated slaves brought into question the so-called universality and objectivity of their French master's Declaration of the Rights of Man, and when, following Toussaint Louverture's radical abolition of slavery, they had to defeat the formidable army Napoleon dispatched to re-enslave them. Since they declared their independence in 1804, Haitians have therefore been keenly aware of the inherent conflicts and contradictions of what Colin Dayan has called "white enlightenment,"6 and have often exposed or attempted to solve these problems by tackling their scientific and ideological foundations.

In what follows, I examine a play published in Port-au-Prince in 1820 entitled Le Philosophe-Physicien, which, I argue, is a forgotten forerunner of Firmin's Haitian critique of European science and of Comte's controversial reconciliation of scientific thinking and African fetishism. ${ }^{7}$ Penned by Juste Chanlatte, ${ }^{8}$ this comedy relies on the camera obscura as a prop and a trope to unveil the fetishist aspect of the European idealized conception of scientific knowledge as the transparent projection of truth. When read together with Chanlatte's historical account of the Haitian Revolution, Histoire de la catastrophe de Saint-Domingue (1824), the local and transatlantic interactions at work in the play will become more apparent. They will also prompt a revision of the genealogy of modern science that, beyond Comte's, must include the radical poetics

\footnotetext{
${ }^{6}$ Joan Dayan, Haiti, History, and the Gods (Berkeley: University of California Press, 1995), 242.

${ }^{7}$ Haitian "romantic" literature has traditionally been dismissed as a mere imitation of conventions associated with French Romanticism. But, as Amy Reinsel has argued in her pioneering reevaluation of post-1830 Haitian poetry, " $[\ldots]$ these poems are not remarkable for literary innovation per se but rather for the historical and ideological information they convey." Amy Lynelle Reinsel, Poetry of Revolution: Romanticism and National Projects in Nineteenth-Century Haiti, (2008), http://d-scholarship.pitt.edu/8463 Unrestricted Access. 84.

${ }^{8}$ There is some confusion concerning the author of the play. In Hénock Trouillot's classic study of the history of Haitian literature, when the play is first alluded to, the author is identified as Jules Solime Milscent, the editor of L'Abeille haytienne, the journal where the play appeared. When Trouillot examines more closely the play in a subsequent section, he refers to Juste Chanlatte as its author. Hénock Trouillot, Les Origines sociales de la littérature haïtienne, 2 ed. (Port-au-Prince: Les Editions Fardin, 1986), 41, 49-53.
} 
and politics of Haiti's first leader, Jean-Jacques Dessalines, the magico-religious beliefs of the Haitian peasantry, and the magical tricks of an anonymous young Haitian girl.

\section{Exposing Romanticism's Black Box}

The exposition scene of Le Philosophe-Physicien consists of a dialogue between a "skilled physicist," Gelanor, and his cunning valet, François. To Gelanor's exasperation, François does not perceive the difference between physics and magic, and, to make matters worse, he likens the work of scientists to that of local sorcerers known as "papa-loi." François refers to various miracles performed by papa-loi ranging from resistance to drowning and sharp blades to the extraction of snakes and needles from the legs and heads of sick patients. Gelanor counters that papa-loi only take advantage of credulous people to make money, and proceeds to debunk their magic tricks with rational explanations. In a sly maneuver, François bows down to his master's scientific arguments only to shift the attention to Gelanor's latest invention, "the chamber of truth."

Through the combination of "certain substances" and "liquors," Gelanor created a "fluid" that acts on the brain in order to reveal one's "most secret thoughts." This fluid operates in "the chamber of truth," a room he constructed next to his lab. Distancing himself from the papa-loi, Gelanor plans on offering the service of his extraordinary machine free of charge, prompting François's quip that no one would like to pay in order to hear "hard truths" about themselves anyways. Gelanor claims that he only wants to help people learn about their and other's true feelings, and that he only has the intention to use the revelations of "the chamber of truth" to acquire a "perfect knowledge of the human heart," and record it in a book.

Science and technology now play the role of messenger of truth and transparency, a role that once belonged to penetrating characters such as Alceste in Molière's The Misanthrope (1666). 
The idea of a machine that would reveal truth within a dark chamber was familiar due to the currency of the camera obscura as an analogy to convey objectivity. ${ }^{9}$ For instance, Kofman shows that Rousseau's Confessions depended on the camera obscura to bring support to its professed transparency. ${ }^{10}$ Rousseau claimed he wanted to write his tell-all book like painters, who, since the Renaissance, relied on the camera obscura to draw more accurately. The camera obscura is a dark chamber that captures the light rays of a model outside through a lens lodged in a small hole, and projects them onto a flat screen inside. This simple optical tool provided painters with a "truthful representation" of the model, on which they could draw their pictures. In Rousseau, the model of the metaphorical camera obscura is his soul, which he vows to represent objectively, as if with no mediation. The professed objectivity of the Confessions depends on its conception as a kind of black box where the truth about its author is supposedly projected through the transparent lens of his introspective writing.

Kofman argues that Rousseau's camera obscura plays the role of a "fetish." It contains another kind of black box where light does not enter because, as his biographers have shown, his desire for absolute transparency keeps as much in the dark as it reveals. Like a fetish, Rousseau's invocation of the camera obscura hides the unknown under the cover of transparency. ${ }^{11}$

Le Philosophe-Physicien also points to the fetishist nature of Gelanor's "chamber of truth." The exposition scene performs a comic reversal when François suddenly becomes the sceptic as he questions the value of Gelanor's invention. François wonders how the scientific extraction of truth can contribute to the greater good when so much sadness and unhappiness could result from

\footnotetext{
${ }^{9}$ Trouillot makes this connection, but I disagree with him that "the chamber of truth" is just a fantasy that takes away from the play's social commentary against superstition. Trouillot, Les Origines sociales de la littérature haïtienne, 49-53.

${ }^{10}$ Kofman notes that Rousseau's reference to the camera obscura occurs in the sketches of the Confessions, but continues to inform the final version through his evocation of painting. Kofman, Camera obscura, de l'idéologie, 56.

${ }^{11}$ Ibid., 53-9.
} 
uncovering the ugly side of humanity, when some illusions are actually "so gentle" (si douce), and when it would ultimately lead to another boring academic book that will remain out of reach of the illiterate masses. Irritated, Gelanor brings the discussion to an end, but not without conceding that, to work properly, his "chamber of truth" also needs a type of magic associated with staging. Gelanor is going to put on a more impressive "costume" because "Although my experiments occur purely through physical means, we must nevertheless endow them with an air of magic."12

Gelanor acknowledges that the scientific revelation of truth also involves theater. In other words, the black box of truth cannot do away with a measure of deceit or untruth. This realization concerning "the chamber of truth" provides a more nuanced account of objectivity than in Rousseau's because it brings back to the fore the historical connection between the camera obscura and theater. Since the Renaissance, the camera obscura and closely related optical devices such as the magic lantern wowed audiences with projections in dark chambers that appeared magical. These illusions made strong impression on spectators, who would accuse respectable technicians of sorcery or believe in charlatans' ability to conjure up evil spirits. By the end of the eighteenth century, these visual tricks were an integral part of phantasmagoria shows, and even participated in the European colonial effort in the Caribbean. During Tacky's Rebellion of 1760, British authorities in Jamaica put magico-religious leaders known as "Obeah-men" on trial for fomenting the slave insurrection. The "Obeah-men" were subjected to interrogation and coercion techniques that involved magic lantern projections and electrical shocks. The projected illusions reportedly failed to impress the prisoners. ${ }^{13}$

\footnotetext{
12 "Bien que mes expériences se fassent par des moyens purement physiques, il faut néanmoins leur donner un air magique" (13)

${ }^{13}$ Bryan Edwards, The History, Civil and Commercial, of the British Colonies in the West Indies, vol. 2 (London: John Stockdale, 1793-1801), 98. See also Justine S. Murison, "Obeah and Its Others: Buffered Selves in the Era of Tropical Medicine," Atlantic Studies 12, no. 2 (2015).
} 
Gelanor's acknowledgement of the theatrical dimension of "the chamber of truth" implies that the Haitian author and audience of Le Philosophe-Physicien did not buy into the projections of the European black box of truth and untruth. Science, like theater, is staged. This realization takes part in a wider nineteenth-century epistemological shift manifested by the changing meaning of the camera obscura metaphor from transparency to opacity. For instance, Karl Marx would mobilize imagery inspired by the camera obscura to convey the phantasmagoric and fetishist nature of ideologies and the commodity. The idealized representation of the objective mind as a disembodied camera obscura where truthful projections occur, would also lose credibility due to scientific advancements concerning the embodied nature of perception. The surreptitious influence of the body on perception pointed to the existence of another black box within the camera obscura of the mind that would receive a striking illustration in Freud's description of the opaque "antechamber" of the unconscious. ${ }^{14}$

In Le Philosophe-Physicien, "the chamber of truth" is a stage within a stage that uncovers secrets. ${ }^{15}$ The remaining scenes of the play parade various couples stepping inside Gelanor's invention and realizing for the most part the deceitful nature of their relationships. What remains in the dark, however, are the Haitian political and epistemological origins of the play's critical mise en abyme of the theoretical model of the camera obscura.

\section{The Politics of Containing the Haitian Peasantry}

When the newspaper L'Abeille haytienne, journal politique et littéraire published Le Philosophe-Physicien during the fall of 1820, Haitian spectators would have recognized that the

\footnotetext{
${ }^{14}$ Crary, Techniques of the Observer: On Vision and Modernity in the Nineteenth Century. See chapters 1 and 2 in Kofman, Camera obscura, de l'idéologie.

${ }^{15}$ The prefatory stage direction for Le Philosophe-Physicien describes a kind of box set divided into two rooms: on one side, Gelanor's lab, on the other, "the chamber of truth."
} 
dialogue on the nature of science and magic between Gelanor and François made direct reference to an incident that had occurred in Port-au-Prince a few months earlier. In early August, a young girl (16-17 years old) became a sensation for reportedly extracting cotton, cigars, and nails from her mouth, and needles, vase fragments, feathers, and fingernails from her eyes and ears. These wonders made so many believers in the supernatural that, a few days later, the government published a scientific pamphlet to strip the girl of her supposed magic power, and to warn against charlatans who exploit the credulity of the superstitious masses.

The author of the anti-superstition pamphlet was Noël Colombel (1786-1823). ${ }^{16}$ Born in Saint Domingue (colonial Haiti) from a French man and a woman of color, Colombel had the opportunity to study medicine and the natural sciences in Paris. ${ }^{17}$ In his pamphlet, through numerous citations of authoritative studies on verified cases where people did dangerously ingest and later evacuate sharp or large objects from their orifices, he deployed his European scientific training to find a rational explanation for the exploits of the young Haitian girl, and render her supernatural power natural.

Colombel was the personal secretary of the president of Haiti, Jean-Pierre Boyer (17761850). Following the assassination in 1806 of Haiti's first chief of state, Jean-Jacques Dessalines, the country split into two: in the North and the Artibonite region, Henry Christophe became president and eventually established a monarchy, and in the South and the West, Alexandre Pétion headed a republic. When Pétion passed away in 1818, Boyer succeeded him as President. During the second half of 1820, the time of publication of Colombel's pamphlet and Chanlatte's play,

${ }^{16}$ C..... Réflexions sur un prétendu prodige opéré au Port-au-Prince dans les premiers jours du mois d'août 1820 (Port-au-Prince). For Colombel as the author of the book, see Antoine-Alexandre Barbier, Dictionnaire des ouvrages anonymes et pseudonymes [...], vol. 3 (Paris: Barrois, 1824), 177.

${ }^{17}$ Charles Nodier and al., Biographie universelle classique, vol. A-G (Paris: Charles Gosselin, 1829), 691. 
Christophe, in poor health and facing a coup, committed suicide, and Boyer achieved the reunification of Haiti. ${ }^{18}$

During his autocratic reign (1818-1843), Boyer would also unify Haiti's legal system. From 1825 to 1835 , Boyer's government produced new Haitian codes of laws. Haiti's codes derived mainly from those of the French except for a section located in the 1835 Code Pénal entitled "Des sortilèges" (on spells). This section condemns spell and fetish makers and fortunetellers to imprisonment and fines, and warrants the confiscation of their "instruments" and "costumes."

In her meticulous study on the interactions of the law and spiritual practices in Haiti, Kate Ramsey has examined the local and transatlantic implications of this "anomalous section" of the Code Pénal. Haitian Independence was met with international coldshouldering and bad press, which questioned the ability of black people to rule a "civilized" state. Boyer's legal crackdown on sorcery sent a clear signal to Europeans that the Haitian elite actively fought what whites considered "savage" beliefs associated with Africa. This strategy backfired. Haiti's detractors began to use the Code Pénal as an official acknowledgment of black magic, and, in turn, as undeniable evidence of Haiti's backwardness.

At home, the criminalization of sorcery participated in wider political maneuvers meant to subdue and politically marginalize the peasantry. The Haitian peasantry emerged during the Revolution when emancipated black slaves, rejecting the colonial plantation system, yearned to work their own plot of land. But, beginning with Toussaint Louverture, Haiti's early leaders considered this shift from proto- to pre-industrial agricultural production as a threat to Haiti's economic growth and security. They resisted this shift through the imposition of various types of

\footnotetext{
${ }^{18}$ Kate Ramsey, The Spirits and the Law : Vodou and Power in Haiti (Chicago: University of Chicago Press, 2011), 56-7.
} 
militarized or state controlled agriculture reminiscent of the colonial plantation system that did not fare well with emancipated slaves and their descendants.

The section on sorcery of the Code Pénal helped extend the government's power over peasants by targeting their magico-religious beliefs. The section's categorization of spells and fetishes - "ouangas, caprelatas, vaudoux, donpèdre, macandals" - marks the sudden appearance of the vernacular in a volume written in French, the official language of the state. Listed without definitions, these wide ranging terms are ambiguous. They could simultaneously refer to fetishes (ouangas, macandals), sorcerers/charlatans (caprelatas, macandals), magic/sorcery (ouangas, macandals, donpèdre), and religious rituals (vaudoux, donpèdre). Ramsey considers the grouping of these multifarious terms under the sorcery category as contradictory because it conflates malevolent work with peasant spirituality, or what would later be known as the Vodou religion. This conflation provided Boyer's government with the legal means to repress peasant magicoreligious rituals that had played an integral role in fomenting the slave insurrection that led to Haitian Independence, but that it now considered as a threat to the authority of the Haitian state. ${ }^{19}$ A proto-Vodou gathering of slave leaders known as the ceremony of Bois Caïman allegedly sparked the Haitian Revolution. During the violent struggle that followed, a report on captured slave insurgents mentions that they were carrying both French pamphlets on the Rights of Man as well as fetishes. These fetishes were "garde-corps," or protective talismans, which were little sacks "full of hair, herbs, bits of bone." ${ }^{20}$ Ramsey deems these magical objects "a powerful political resource" as they embolden their carriers on the battlefield. ${ }^{21}$ Another contemporary report

\footnotetext{
${ }^{19}$ Ibid., 58-71. See also Laënnec Hurbon, Le Barbare imaginaire, Sciences humaines et religions (Paris: Cerf, 1988).

${ }^{20}$ My Odyssey: Experiences of a Young Refugee from Two Revolutions, trans. Althéa de Puech Parham (Baton Rouge: Louisiana State University Press, 1959), 33-4.

${ }^{21}$ Ramsey, The Spirits and the Law : Vodou and Power in Haiti, 44.
} 
describes more ostentatious fetishes that worked as a kind of religious and military rallying point: "The Voodoo king had just declared war on the colonials, and, diadem circling his forehead, and accompanied by the queen dressed in a red scarf, and agitating the little bells decorating a box containing a snake, they were marching to the assault of the colony's cities." ${ }^{22}$

The snake in the box refers to Dambala, a deity of African origin that continues to play a central role in the Vodou pantheon, and that Haitians associate, among other things, with good luck. ${ }^{23}$ Although not mentioned by name, Dambala's symbol figured prominently in the first detailed description of slave religious rituals recorded by Moreau de Saint-Méry, just a few years before the ceremony of Bois Caïman. ${ }^{24}$ In Saint-Méry's account, participants in a "Vaudoux dance" congregate around their "King" and "Queen," and a see-through box containing a snake (une couleuvre) which channels "Vaudoux"-_[a]n all-powerful supernatural being on which depend all the events on earth [...] knowledge of the past, present and future." The devotees plead for the magical power of "Vaudoux" to help them solve their problems and fulfill their aspirations and, Saint-Méry significantly notes, the ability to control their master's mind. Then, the queen stands on the box, becomes possessed by the snake's spirit, and "the oracle speaks through her mouth." ${ }^{25}$

The magico-religious beliefs that had empowered slaves during the uprising acquired a very ambiguous status in postrevolutionary Haiti. Christophe applied the death penalty against

\footnotetext{
${ }^{22}$ Cited in Jean Fouchard, The Haitian Maroons: Liberty or Death (New York: E.W. Blyden Press, 1981), 346. On the same page, Fouchard also quote early Haitian historian Thomas Madiou's account of revolutionary leaders who "ruled by superstition" and who marched preceded by "sorcerers, or papas."

${ }^{23}$ Zora Neale Hurston, Tell My Horse : Voodoo and Life in Haiti and Jamaica (New York: Perennial Library, 1990), 119.

${ }^{24}$ M. L. E. Moreau de Saint-Méry, Description topographique, physique, civile, politique et historique de la partie française de l'isle Saint-Domingue [...], ed. I. Sonis and J. Vallance, 2 vols. (Philadelphie1797), 45-52. The translations are mine.

${ }^{25}$ She is "possessed [pénétrée] by God. She shakes, her whole body convulsed, and the oracle speaks through her mouth." A convulsive dancer later experiences what Saint-Méry refers to as "mount Vaudoux" (monter Vaudoux) $48-9$.
} 
"papas-loi," ${ }^{26}$ which did not stop him from enlisting their services, along with that of "mamansloi," in his political and military scheme to overthrow Pétion. In the early 1810 s, they played an integral role in his strategy to capture Port-au-Prince, Pétion's capital city. To tame the inhabitants of Port-au-Prince and its surrounding region, Christophe paid some of these religious leaders to preach about the divine nature of his mission in "Vaudoux" ceremonies. He even staged a miracle that involved a spy impersonating the Virgin Mary on a "cursed" tree, and announcing a great misfortune to anyone who would resist his army. The fake apparition drew to its site a large number of devotees from the city of Port-au-Prince until Pétion dispatched an abbot to burn the tree down, and expose Christophe's charlatan. ${ }^{27}$

The magico-religious beliefs that had contributed to the formation of alternative and secret slave communities during colonial times, and that had emerged as a pivotal rallying point on the eve of the Revolution, posed a threat to public order. In 1814, Pétion prohibited "all dance groups [corporations]... or associations which foster an esprit de corps and a hierarchy of position in their denominations." According to one of Haiti's earliest historians, Beaubrun Ardouin (1796-1865), the law targeted various highly organized and hierarchical societies that had appeared in Port-auPrince "under the pretext of indulging in the dances of the country." ${ }^{28}$ Popular meetings and rituals associated with the country (pays) had a detrimental influence on the city, and manifested power and political structures that operated beyond state control.

Pétion's law signals a deep divide between the city and the country that will become even more apparent in Boyer's disenfranchisement of the peasantry in the Code Pénal and, before that,

\footnotetext{
${ }^{26}$ In 1805, Christophe, who was at the time the commander-in-chief of Dessalines's army, had already ordered a repressive campaign in the North against the "danses de vodou." Ramsey, The Spirits and the Law : Vodou and Power in Haiti, 51.

${ }^{27}$ Thomas Madiou, Histoire d'Haïti: 1811-1818, vol. 5, Histoire d'Haïti (Port-au-Prince: Editions Henri Deschamps, 1988), 111-2.

${ }^{28}$ Cited and translated in Ramsey, The Spirits and the Law : Vodou and Power in Haiti, 52.
} 
in the publication of scientific pamphlets claiming to fight superstition. ${ }^{29}$ As Colombel demystifies the magic tricks of the young girl who had created such a stir in Port-au-Prince during the summer of 1820 , he makes a list of superstitions which, anticipating the ambiguous section "on spells" of the Code Pénal, conflates sorcery and peasant spirituality: "all of these ridiculous tales of sorcerers, soothsayer, magicians, [...] revenants, zombies, werewolves, vaudoux, gangans, macandas, ouangas $[\ldots] .{ }^{30}$ Like the criminalization of sorcery in the Code Pénal, Colombel also addresses readers abroad who, upon hearing about those local tales, might accuse Haiti of backwardness, by reminding them that, from the oracles of antiquity to the recent craze for a "charlatan" like Mesmer, Europeans have been just as credulous. In his conclusion, Colombel evokes "the weapon of humor [plaisanterie]" and "the salt of irony" as welcomed complements to his scientific mission to dispel the illusions leading humanity astray. ${ }^{31}$

Chanlatte answered Colombel's call in Le Philosophe-Physicien, a comedy inspired by the same event that had fascinated so many in Port-au-Prince (the play's papa-loi extracts various objects from his body just like the young girl). However, Chanlatte's play offers a more sophisticated account of credulity than the anti-superstition pamphlet of Boyer's secretary. The exposition scene pokes fun at the belief in magic as well as points to the fetishist aspect of European science through the mis en abyme of one of its traditional theoretical models, the camera obscura. Gelanor's concession that his "chamber of truth" needs an "air of magic" linked to staging and theater, blurs the line between European science and fetishism and valorizes the latter's epistemological function. This valorization worked against the political motivation of Boyer's

\footnotetext{
${ }^{29}$ Colombel wrote at least another anti-superstition pamphlet in 1819 to reassure the inhabitants of Port-au-Prince that the "meteor" they had recently seen in the sky was not a sign of imminent calamity. Thomas Madiou, Histoire d'Haïti: 1819-1826, vol. 6, Histoire d'Haïti (Port-au-Prince: Editions Henri Deschamps, 1988), 27.

${ }^{30} \mathrm{C}$..... Réflexions sur un prétendu prodige opéré au Port-au-Prince dans les premiers jours du mois d'août 1820, 4. My translation.

${ }^{31}$ Ibid., 16.
} 
government since it presents local magico-religious beliefs associated with the peasantry in a more favorable light.

Le Philosophe-Physicien appeared around the time Chanlatte, following the suicide of his old patron King Christophe, pledged his allegiance to President Boyer. Scholars have often criticized Chanlatte for his lack of loyalty. ${ }^{32}$ But, I would argue, in the unstable political climate that marked the early years of Haiti, Chanlatte's noncommittal and opportunist attitude put him in a less constraining position from which, under the cover of irony, he could express opinions that would not necessarily follow state directives. The politically and epistemologically transgressive opinions - both at home and abroad-expressed in Le Philosophe-Physicien appear more concretely in Chanlatte's Histoire de la catastrophe de Saint-Domingue (1824). Published anonymously in Paris, this hybrid text mixing eye-witness accounts, philosophical meditations, diplomatic outreach, and historical documents is an attempt to come to terms with the extreme violence that marked the end of the Haitian Revolution. ${ }^{33}$ A closer look at this work will show that Chanlatte's remarkable views on peasant fetishism and science originated in the mind of JeanJacques Dessalines.

\section{The Theater of the Catastrophe of Saint Domingue}

In the opening pages of Histoire de la catastrophe de Saint-Domingue, Chanlatte makes his aim clear: to tear away the European "magic gauze" (gaze magique) hiding the truth about the

\footnotetext{
32 Trouillot, Les origines sociales de la littérature haïtienne, 29, 63-7.

33 Juste Chanlatte and Auguste Jean Baptiste Bouvet de Cressé, Histoire de la catastrophe de Saint-Domingue [...] (Paris: Peytieux 1824). Bouvet de Cressé, a former officer of the French navy, edited the book. He attributes the manuscript to a distinguished member of Henry Christophe's army, "J...E Ch.......E." But, by the time of publication, Chanlatte had been working for Boyer for about four years. This anachronism probably comes from the fact that the book was a slightly amended new edition of Chanlatte's older work, Le Cri de la nature (1810). See footnote 63 in Pompée-Valentin Vastey and Chris Bongie, The Colonial System Unveiled (Liverpool: Liverpool University Press, 2014), 159. Bongie notes that Vastey's groundbreaking anti-colonial pamphlet included some passages lifted from Chanlatte's Histoire.
} 
"horrors of the colonial system." ${ }^{34} \mathrm{He}$ first gets into the black box of slavery by unveiling its scientific foundation; more particularly, the ongoing debate between monogenist and polygenist conceptions of the origin of human races. Chanlatte argues that the explanation of human differences in terms of multiple origins has been misleading and facilitated the brutal exploitation of blacks. The theory of the shared root and unity of human diversity is, for its part, obvious and receives ample empirical justifications in the numerous African intellectual achievements recorded throughout history. ${ }^{35}$

Chanlatte follows his epistemological argument with a "moral" one. ${ }^{36}$ In the wake of the slave insurrection that led to Haitian Independence, he invokes the ability of blacks to revolt against their masters and avenge the harm done to them as further proof of their humanity. Chanlatte concludes his critical observations by reversing the traditional roles assigned to Europeans and Africans. By denying blacks human dignity in order to profit from their slave labor, Europeans have been "charlatans" who have taken advantage of their advanced civilization to perform the worst acts of barbarism. ${ }^{37}$ Born in the "theater" where European achievement and regression once reached an unprecedented synthesis, Haiti could be the site of a "virgin energy" that will throw "light" on the inherent contradiction of white civilization. ${ }^{38}$

Chanlatte's association of the "horrors of the colonial system" with "theater" is not simply metaphorical. His book contains eye-witness accounts and historical documents detailing the treacheries and the often staged atrocities performed by colonists and the army that Napoleon dispatched to Saint Domingue to reinstate slavery. Beyond false proclamations of human rights

\footnotetext{
${ }^{34}$ Chanlatte and Bouvet de Cressé, Histoire de la catastrophe de Saint-Domingue [...]. 5, 20. The translations are mine.

${ }^{35}$ For a detailed examination of these debates see Andrew S. Curran, The Anatomy of Blackness: Science \& Slavery in an Age of Enlightenment (Baltimore: Johns Hopkins University Press, 2011).

${ }^{36}$ Chanlatte and Bouvet de Cressé, Histoire de la catastrophe de Saint-Domingue [...]. 9.

${ }^{37}$ Ibid., 19, 27.

${ }^{38}$ Ibid., 29-30, 49.
} 
for all and the dishonorable arrest of Toussaint Louverture, the French conducted a war of racial extermination, which included public torture and execution that became spectacles reminiscent of "the blood-soaked Roman circuses." 39

Chanlatte focuses particularly on events of absolute cruelty commissioned by General Rochambeau during the last months of French colonial rule in Saint Domingue. Upon his arrival in Port-au-Prince, Rochambeau organized a ball for local ladies in a room he had covered entirely with black crepe and lit up with funerary torches. Once the ladies entered the dark chamber, he announced to them that he had actually convened them to their burial. ${ }^{40}$ Rochambeau's reign of terror culminated in mass and indiscriminate death sentencings. Under his command, children were stabbed, put into bags, and thrown into the sea. Foreshadowing Nazi gas chambers, he crammed men and women into hermetically sealed ship's holds, and asphyxiated them with sulfuric fumes. ${ }^{41}$

Chanlatte devotes his most dramatic and detailed description of Rochambeau's atrocities to a public execution that occurred in Le Cap, and that involved dogs mauling to death a black prisoner tied up to a post. Other accounts of this infamous display of unbounded cruelty exist, but Chanlatte's stresses the disturbing theatricality of the execution, which, he writes, he witnessed and has haunted him ever since. Colonial authorities carefully orchestrated the event to entertain Europeans. In an atmosphere of celebration, colonists gave a hero's welcome to ferocious dogs brought from Cuba, before gathering in a makeshift "amphitheater" in the courtyard of a convent, where they cheered as the canine death squad performed its murderous task. Following the graphic portrayal of the black prisoner's mangled and ripped open body, Chanlatte characterizes what he

\footnotetext{
${ }^{39}$ Ibid., 64.

${ }^{40}$ Ibid., 58. See footnote 1.

${ }^{41}$ Ibid., 61 .
} 
saw in this theater of real horror as a "scene that tears you apart" (scène déchirante), and that decisively dispelled the "magic gauze" of the colonial system: "all imaginary ideas of superiority and color disappeared, man alone remained." ${ }^{42}$ In the wake of this ultimate atrocity, Chanlatte implies, blacks and colored people joined forces and proceeded to overthrow French colonial rule once and for all. He conveys this denouement of the Haitian Revolution in terms of a rallying cry for vengeance that overcame the deadening effects of the colonial system as it drew the insurgent masses out of the dark enclosures of their "sepulchers."

Deborah Jenson notes that Chanlatte's "metaphor of the bloody tatters of the veil of prejudice" derives from Dessalines's "singular rhetorical and poetic ferocity." ${ }^{43}$ Although the black slave turned General and first ruler of Haiti was illiterate, he left his "conceptual voice" in a series of proclamations that marked Haiti's transition from a colonial to a postcolonial state and that constitutes one of the earliest contributions to "radical black Atlantic political theory." 44 Different secretaries, including the young Chanlatte, penned Dessalines's official announcements. In these polyvocal documents, Dessalines's conceptual voice transpires through their "anticolonial poetics in the service of the representation of former slaves' experience and subjective claims," and through his sustained critique of European civilization and what he called its "idols" and "relics." $" 45$

Dessalines's association of European civilization and fetishism does not simply reenact the white dismissal of black magico-religious beliefs against the whites themselves. As Jenson argues, his conceptual voice manifests an unprecedented anticolonial fervor marked by his experience as

\footnotetext{
${ }^{42}$ Ibid., 66-70.

${ }^{43}$ Deborah Jenson, Beyond the Slave Narrative: Politics, Sex, and Manuscripts in the Haitian Revolution (Liverpool University Press, 2011), 89.

${ }^{44}$ Ibid., 115.

${ }^{45}$ Ibid., 96.
} 
a self-emancipated slave warrior, and translated into a poetical and political rhetorical form designed to conjure up a "quasi-magical effect." 46 Chanlatte, then, also drew inspiration from Dessalines when he exposed the "magic gauze" of the colonial system and questioned the European distinction between magic and science in The Philosophe-Physicien.

As his personal secretary, Chanlatte must have had a close relationship with Haiti's first black head of state, who had close ties with the magico-religious beliefs of the peasantry, and who was the only revolutionary leader to become a spirit $(l w a)$ in the Vodou pantheon. ${ }^{47}$ Chanlatte helped Dessalines write several official announcements, including the one in which he famously boasted: "I have avenged America." Dated April 28, 1804, this proclamation appeared in the wake of the Declaration of Independence and soon after Dessalines condoned the extermination of the few thousand whites who had remained in Haiti. ${ }^{48}$ This brutal reprisal became an embarrassing event in Haiti's early history that Chanlatte would also attempt to expiate in his Histoire de la catastrophe de Saint-Domingue. Chanlatte's account of the horror of slavery, the treacheries of Napoleon's expedition, and Rochambeau's ultimate atrocities makes a clear causal link between the inherent violence of the French colonial system and that of the unrestrained revenge against whites. Chanlatte also points out European historical precedents of similar outbursts of violence by drawing a parallel between the post-Independence massacres and the Reign of Terror of the French Revolution.

The multiple unveilings of truth performed in Histoire de la catastrophe de SaintDomingue put on display the charlatanism of French colonial authorities, who, under the cover of science and revolutionary ideals, were in fact the "enemies of the rights of man." ${ }^{49}$ Beyond this

\footnotetext{
${ }^{46}$ Ibid., 96-7.

${ }^{47}$ Ramsey, The Spirits and the Law : Vodou and Power in Haiti, 49.

${ }^{48}$ Beaubrun Ardouin, Études sur l'histoire d'Haïti, vol. 6 (Paris: Chez l'auteur, 1856), 67.

${ }^{49}$ Chanlatte and Bouvet de Cressé, Histoire de la catastrophe de Saint-Domingue [...]. 81.
} 
reversal, Chanlatte brings forth other more hermetic or bottomless black boxes. The circle of violence and revenge that marked the Haitian Revolution becomes a stage from which his readers can fathom the abyss of human cruelty as well as peek into possible futures. ${ }^{50}$ The former reveals a common predisposition to commit atrocities that helps Chanlatte's overall strategy to undermine the racist opposition between black and white. The latter gives him the opportunity to issue a warning against any European plans to re-colonialize his land. It also enables him to envision a better time to come where, beyond the cycle of vengeance, the "New" and "Old" worlds would reconcile and contribute to each other's political and economic development. Chanlatte concludes that "[d]espite the thickness of the veil that still covers this seducing future, the imagination takes pleasure in lifting a corner of the curtain. ${ }^{, 51}$ What his imagination perceives is an allegory of truth as a "palace sparkling with transparency," built upon "vast ruins," and uncovered by the "hand" of "time." 52

Histoire de la catastrophe de Saint-Domingue is an attempt to get the "palace" of truth off the ground. Like the "chamber of truth" in Le Philosophe-Physicien, transparency can lead to permanent ruptures or eventual reconciliation. In the play, Gelanor's machine reveals the deceitful nature of several relationships, prompting dramatic breakups, except for one couple, two friends who are the only characters identified as French people (Le Normand and Le Gascon). Despite embarrassing revelations, their friendship survives the test of truth and they move on without "ressentiment." (47) No such happy ending occurred in the relationship between France and Haiti. In 1825, the year following the publication of Histoire de la catastrophe de Saint-Domingue, the French government, in exchange for diplomatic recognition, forced Boyer to repay an enormous

\footnotetext{
${ }^{50}$ Ibid., 71, 93.

${ }^{51}$ Ibid., $92-3$.

${ }^{52}$ Ibid., 97.
} 
indemnity in the name of the planters who had lost their "properties" due to the slave insurrection.

This debt would cripple Haiti's economic development well into the twentieth-century.

\section{Epilogue}

Inspired by Dessalines's radical anticolonial politics and poetics, Chanlatte's Le Philosophe-Physicien and Histoire de la catastrophe de Saint-Domingue are chambers of truth founded on the ruins of the colonial system that manifest a new epistemology emerging from Haiti's unprecedented postcolonial experiment. Marked by hybridity, the truthfulness and critical power of this epistemology derives from its reconciliation of science and fetishism, which received a striking demonstration in the ironic mise en abyme of the camera obscura in Le PhilosophePhysicien. On this Haitian stage, Chanlatte shows that the black box or "chamber of truth" of European science is in fact a fetish. Schematically, this kind of fetish takes the form of a black box concealing another black box. ${ }^{53}$ In addition to the phantasmagoric nature of the camera obscura, the black box within can hide other types of secrets such as the abyss of human cruelty that Chanlatte uncovers in Rochambeau's dark chambers of horror and staged atrocities.

The fetish that Chanlatte puts on stage also establishes a syncretic connection that brings to the fore the magico-religious beliefs of the disenfranchised Haitian peasantry. Slave insurgents carried fetishes containing magic deriving from the hidden combination of heteroclite objects such as hair, herbs, and bits of bone, and Dambala emboldened many others through a snake in a box. These fetishes from the revolutionary era resonate with the enclosed structure found in Chanlatte's

\footnotetext{
${ }^{53}$ Later, Hurston would learn about similar fetishes as a "little box in a big box." Hurston, Tell My Horse : Voodoo and Life in Haiti and Jamaica, 188. Some of the more recent descriptions of these fetishes include an optical component such as mirrors. Elizabeth McAlister, "A Sorcerer's Bottle: The Visual Art of Magic in Haiti," in Sacred Arts of Haitian Vodou, ed. Donald Cosentino (Los Angeles: UCLA Fowler Museum of Cultural History, 1995). See also Nick Nesbitt, Voicing Memory: History and Subjectivity in French Caribbean Literature (Charlottesville: University of Virginia Press, 2003), 40-2.
} 
play. Although Chanlatte mocks fetish makers such as the papa-loi, his ultimate target is the European idealized conception of knowledge as the transparent projection of truth. Within this context, the anonymous young Haitian girl who, as if her body were a fetish, extracted from it cotton, cigars, nails, needles, vase fragments, feathers, and fingernails, and who prompted a state rebuttal in Colombel's anti-superstition pamphlet as well as inspired Chanlatte's sophisticated critique of European science in Le Philosophe-Physicien, left an indelible mark in the emergence of modern science. 


\section{Works Cited}

My Odyssey: Experiences of a Young Refugee from Two Revolutions. Translated by Althéa de Puech Parham. Baton Rouge: Louisiana State University Press, 1959.

Ardouin, Beaubrun Études sur I'histoire d'Haïti. Vol. 6, Paris: Chez l'auteur, 1856.

Bailey, Lee W. "Skull's Darkroom: The Camera Obscura and Subjectivity." In Philosophy of Technology: Practical, Historical and Other Dimensions, edited by Paul T. Durbin, 63-79: Springer Netherlands, 1989.

Barbier, Antoine-Alexandre Dictionnaire des ouvrages anonymes et pseudonymes [...]. Vol. 3, Paris: Barrois, 1824.

C..... Réflexions sur un prétendu prodige opéré au Port-au-Prince dans les premiers jours du mois d'août 1820. Portau-Prince.

Canguilhem, Georges. Études d'histoire et de philosophie des sciences. 3 ed. Paris: Librairie philosophique J. Vrin, 1975.

Chanlatte, Juste. "Le Philosophe-Physicien." L'Abeille haytienne, journal politique et littéraire, 1820, 5-53.

Chanlatte, Juste, and Auguste Jean Baptiste Bouvet de Cressé. Histoire de la catastrophe de Saint-Domingue [...]. Paris: Peytieux 1824.

Comte, Auguste. Cours de philosophie positive. Vol. 5, Paris: J.P. Baillère et Fils, 1864.

- - . Système de politique positive. Vol. 3, Paris: Librairie des corps impériaux des ponts et chaussées et des mines, 1853.

Crary, Jonathan. Techniques of the Observer: On Vision and Modernity in the Nineteenth Century. Cambridge: MIT Press, 1990.

Curran, Andrew S. The Anatomy of Blackness: Science \& Slavery in an Age of Enlightenment. Baltimore: Johns Hopkins University Press, 2011.

Dayan, Joan. Haiti, History, and the Gods. Berkeley: University of California Press, 1995.

Edwards, Bryan. The History, Civil and Commercial, of the British Colonies in the West Indies. Vol. 2, London: John Stockdale, 1793-1801.

Firmin, Joseph-Anténor. De L'égalité des races humaines (anthropologie positive). Paris: F. Pichon, 1885.

Fouchard, Jean. The Haitian Maroons: Liberty or Death. New York: E.W. Blyden Press, 1981.

Hurbon, Laënnec. Le Barbare imaginaire. Sciences humaines et religions. Paris: Cerf, 1988.

Hurston, Zora Neale. Tell My Horse : Voodoo and Life in Haiti and Jamaica. New York: Perennial Library, 1990.

Jenson, Deborah. Beyond the Slave Narrative: Politics, Sex, and Manuscripts in the Haitian Revolution. Liverpool University Press, 2011.

Kofman, Sarah. Camera obscura, De l'idéologie. Paris: Éditions Galilée, 1973.

Madiou, Thomas. Histoire d'Haïti: 1811-1818. Histoire d'Haïti. Vol. 5, Port-au-Prince: Editions Henri Deschamps, 1988.

- - . Histoire d'Haïti: 1819-1826. Histoire d'Haïti. Vol. 6, Port-au-Prince: Editions Henri Deschamps, 1988.

McAlister, Elizabeth. "A Sorcerer's Bottle: The Visual Art of Magic in Haiti." In Sacred Arts of Haitian Vodou, edited by Donald Cosentino, 305-21. Los Angeles: UCLA Fowler Museum of Cultural History, 1995.

Moreau de Saint-Méry, M. L. E. Description topographique, physique, civile, politique et historique de la partie française de l'isle Saint-Domingue [...]. Edited by I. Sonis and J. Vallance2 vols. Philadelphie1797.

Murison, Justine S. "Obeah and Its Others: Buffered Selves in the Era of Tropical Medicine." Atlantic Studies 12, no. 2 (2015): 144-59.

Nesbitt, Nick. Voicing Memory: History and Subjectivity in French Caribbean Literature. Charlottesville: University of Virginia Press, 2003.

Nodier, Charles, and al. Biographie universelle classique. Vol. A-G, Paris: Charles Gosselin, 1829.

Ortel, Philippe. La Littérature à l'ère de la photographie : Enquête sur une Révolution invisible. Nîmes: J. Chambon, 2002.

Ramsey, Kate. The Spirits and the Law : Vodou and Power in Haiti. Chicago: University of Chicago Press, 2011.

Reinsel, Amy Lynelle. Poetry of Revolution: Romanticism and National Projects in Nineteenth-Century Haiti. 2008. http://d-scholarship.pitt.edu/8463 Unrestricted Access.

Trouillot, Hénock. Les Origines sociales de la littérature haïtienne. 2 ed. Port-au-Prince: Les Editions Fardin, 1986.

Vastey, Pompée-Valentin, and Chris Bongie. The Colonial System Unveiled. Liverpool: Liverpool University Press, 2014. 